\title{
RELEVANSI SISTEM CIVIL LAW DAN COMMON LAW DALAM PENGATURAN HUKUM PERJANJIAN BAKU DI INDONESIA
}

\author{
Ernu Widodo \\ Fakultas Hukum Universitas Dr. Soetomo Surabaya \\ E-mail:erwidos3@yahoo.com
}

\begin{abstract}
Abstrak
Legislation and court decisions have limited the power of the freedom principle of contract enforcement. In the business world, it has been imposed the restrictions on the principle of freedom of contract through a standard agreement (standard contract). In the practice realm, this restriction do not preclude the parties to fulfill their legal interests through definite agreement. This kind of agreement has been growing to meet legal needs of society despite its substantial and procedural material has not fulfilled the principle of freedom of contract. This assessment system is to show the relevance of the Civil Law and Common Law in the development of standard contract arrangement.

Peraturan perundang-undangan dan putusan pengadilan telah membatasi daya berlakunya asas kebebasan berkontrak. Di dalam dunia bisnis, telah diberlakukan pembatasan pula atas asas kebebasan berkontrak melalui perjanjian baku (standard contract). Di dalam prakteknya, pembatasan tersebut tidak menghalangi para pihak untuk memenuhi kepentingan hukumnya melalui perjanjian baku. Perjanjian baku semakin berkembang dalam memenuhi kebutuhan hukum masyarakat meskipun perjanjian baku baik secara substansiil maupun prosedural belum memenuhi sepenuhnya berlakunya asas kebebasan berkontrak. Pengkajian ini hendak menunjukkan relevansi sistem Civil Law dan Common Law dalam pengembangan pengaturan perjanjian baku.
\end{abstract}

Kata Kunci: Civil law system, Common Law system, Hukum Perjanjian baku.

Mariam Darus Badrulzaman mengutip tulisan Pitlo bahwa seorang ahli filsafat Yunani yang bernama Heraclitus telah mengungkapkan sebuah pernyataan yang penting artinya di dalam kehidupan manusia yang berbunyi: 'pantarei', yaitu segala sesuatu berubah atau 'all things flow'. ${ }^{1}$ Sejalan dengan pemikiran 'pantarei' maka dapatlah dipahami sebagai tanda kehidupan suatu masyarakat adalah kenyataan yang tak dapat diingkari adanya suatu perubahan.

Masyarakat bergerak ke arah perubahan, termasuk hukum yang inheren dalam

\footnotetext{
${ }^{1}$ Mariam Darus Badrulzaman, Perjanjian Baku (Standard): Perkembangannya Di Indonesia dalam Kumpulan Pidato-Pidato Pengukuhan (Bandung: Alumni, 1981)..., 2.
}

kehidupan masyarakat. Salah satu fungsi hukum adalah mengabdi dan menjaga pergerakan yang ada pada masyarakat menuju ke arah perubahan sehingga dapat berjalan tertib dan berkeadilan. Oleh karena itu untuk memenuhi kepentingan-kepentingan masyarakat yang menuju ke arah perubahan (transisi) maka tidak dapat dihindari kebutuhan akan pembaharuan hukum yang diupayakan dapat mengakomodasi kepentingan-kepentingan yang ada dan baru di masyarakat.

Sebagaimana halnya dengan adanya pergerakan perubahan masyarakat-masyarakat di dunia atau negara-negara yang sedang berkembang lainnya, maka Indonesia juga 
mengalami suatu proses pergerakan menuju ke arah perubahan (transisi). Dalam hal ini proses transisional meliputi aneka macam kehidupan di masyarakat, diantaranya adalah bidang hukum. Salah satu aspek bidang hukum yang memasuki proses transisional adalah dari sistem hukum tidak tertulis menuju sistem hukum tertulis.

Pergeseran dari hukum tidak tertulis menuju hukum tertulis (hukum perundang-undangan) menurut Soetandjo Wignjosoebroto yang mengutip pendapat Niklas Luhman, bahwa positivisasi hukum selalu memperoleh prioritas utama dalam setiap upaya pembangunan hukum di negara-negara yang tengah tumbuh berkembang dan menghendaki kesatuan dan atau penyatuan, tak cuma yang menuju ke nation state melainkan juga yang dulu menuju ke colonial state. Positivisasi hukum selalu berhakikat sebagai proses nasionalisasi dan etatisasi hukum dalam rangka menyempurnakan kemampuan negara dan pemerintah (sebagai pengemban kekuasaan negara) untuk memonopoli kontrol sosial yang formal melalui pemberlakuan atau pendayagunaan hukum positif (notabene adalah hukum perundangundangan). ${ }^{2}$

Salah satu bidang hukum yang mengalami masa transisional tersebut adalah bidang hukum perdata. Bidang hukum perdata ini adalah hukum perdata tertulis sebagaimana tercantum dalam Kitab Undang-Undang Hukum Perdata beserta segenap peraturanperaturan khusus (yang berwujud undangundang, peraturan pemerintah, keputusan pemerintah, keputusan presiden, keputusan menteri dan lain-lain) yang ada yang meliputi semua aspek-aspek hukum perdata, sebagaimana tumbuh dan berkembang, sampai perkembangannya terbaru sesuai dengan perkembangan kebutuhan masyarakat dan modernisasi hukum pada umumnya serta menunjang perkembangan ekonomi dan pembangunan pada khususnya. Hal demikian itu berarti pengertian hukum perdata

${ }^{2}$ Soetandyo Wignyosoebroto, Dari Hukum Kolonial Ke Hukum Nasional: Suatu Kajian Dinamika Sosial Politik Dalam Perkembangan Hukum Di Indonesia (Jakarta: Raja Grafindo Persada, 1994)..., h 13. tidak hanya identik dengan Kitab UndangUndang Hukum Perdata (KUH Perdata), melainkan lebih luas sebab di dalamnya tercakup semua peraturan-peraturan baru, peraturan-peraturan modern yang berubah dan berkembang sebagaimana tercantum dalam perundang-undangan negara Republik Indonesia yang tumbuh dan berkembang pada masa kemerdekaan dan dikenal dalam praktek perbankan, perkreditan, jaminan, perindustrian, penanaman modal, perjanjian pemborongan dan lain-lain. Di dalam prakteknya berbagai transaksi hukum yang sejalan dan memenuhi kebutuhan masyarakat sering menggunakan perjanjian baku (standar).

Sejak beberapa puluh tahun terakhir ini berkenaan dengan asas kebebasan berkontrak telah mendapat pembatasan baik yang berasal dari negara berupa peraturan perundang-undangan dan putusan pengadilan maupun pembatasan dengan diberlakukannya perjanjian-perjanjian baku dalam dunia bisnis. Demikian kuatnya pembatasan terhadap asas kebebasan berkontrak sebagai akibat digunakannya perjanjian-perjanjian baku dalam dunia bisnis oleh salah satu pihak, sehingga bagi pihak lainnya kebebasan yang tinggal hanyalah berupa pilihan antara menolak atau menerima (take it or leave it) syarat-syarat perjanjian baku yang disodorkan kepadanya. ${ }^{3}$

Dalam kaitannya dengan arus perubahan masyarakat baik dari kondisi internal maupun kondisi eksternal maka sangat diperlukan suatu pengkajian yang mendalam tentang aspek-aspek hukum perjanjian incasu perjanjian baku (standar) yang meliputi asasasas, konsepsi-konsepsi, teori-teori, aturanaturan hukum termasuk kebiasaan yang dapat dijadikan landasan hukum perjanjian Indonesia sehingga bisa diharapkan dapat menyelesaikan masalah-masalah hukum bagi masyarakat Indonesia khususnya serta masalah yang menyangkut kondisi transisional maupun pengaruh globalisasi.

Beranjak dari latar belakang permasalahan

${ }^{3}$ Sutan Remy Syahdeini, Kebebasan Berkontrak dan Perlindungan yang Seimbang Bagi Para Pihak dalam Perjanjian Kredit Bank di Indonesia (Jakarta: Institut Bankir Indonesia, 1997)..., h 65. 
di atas maka dapat ditarik suatu permasalahan bagaimana relevansi sistem Civil Law dan Common Law dalam perkembangan hukum perjanjian incasu pengembangan asas-asas, konsepsi-konsepsi, dan pengaturan hukum perjanjian baku (standar) di Indonesia.

\section{Klasifikasi Kelompok Hukum yang Berlaku di Dunia}

Menurut Hardiyan Rusli, untuk mengkaji hukum perjanjian incasu perjanjian baku (standar), kiranya perlu mengungkap pendapat Rene David dan John E.C.Brierly, yaitu adanya klasifikasi empat kelompok Hukum Romano-Germanic (civil law), Socialist Law, Common Law, dan other conception of Law. Adapun sebagai landasan dalam kajian ini hanya dua kelompok hukum yang dominan, yaitu Civil Law dan Common Law atau Anglo American Law. ${ }^{4}$ Wilayah Civil Law yang penting adalah Eropa daratan dan Amerika latin dan juga meliputi Indonesia berdasarkan tradisi dan sejarah. Landasan bersama kelompok ini adalah diterimanya hukum Romawi (reception of the Roman Law). Berkembangnya sistem hukum Romawi Jerman adalah berkat usaha dari Napoleon Bonaparte yang berusaha menyusun Code Civil atau Code Napoleon dengan bersumber hukum Romawi. Sistem hukum ini pertama kali berkembang dalam hukum perdatanya atau Civil Law.

Berikutnya yang termasuk kelompok Anglo Amerika adalah Inggris, Irlandia, Australia, Selandia Baru, Canada (kecuali Quebec), dan Amerika Serikat (kecuali Lousiana). Sistem Common Law bersumber dari hukum Inggris yang berkembang dari ketentuan atau hukum yang ditetapkan hakim dalam keputusan-keputusannya (judge made law). Perkataan Common Law ini berasal dari 'comune, ley', yang berarti adalah suatu adat kebiasaan (custom) yang bersifat umum bukan hanya adat kebiasaan setempat/lokal.

Menurut Hardiyan Rusli dengan mengutip pandangan Rene David dan John E.C. Brierly bahwa pada abad kesebelas dapat dikatakan bahwa adat kebiasaan yang bersi-

\footnotetext{
${ }^{4}$ Hardijan Rusli, Hukum Perjanjian Indonesia dan Common Law (Jakarta: Pustaka Sinar Harapan, 1996).., h15
}

fat umum belum terbentuk sehingga pengadilan dari orang-orang yang bebas (freeman) disebut 'County' atau 'Hundred Courts' hanya menerapkan adat kebiasaan setempat yang berbeda-beda. Oleh karena itu di negaranegara dengan sistem Common Law terdapat ketidakpastian hukum dan untuk menghindari hal tersebut, maka mulai abad ke sembilan belas berpegang pada asas hukum 'the rule of precedent', yaitu keputusan-keputusan hakim yang sudah harus menjadi pegangan atau keputusan hakim itu harus mengikuti keputusan hakim sebelumnya. The rule of precedent sering disebut juga sebagai doktrin 'stare decisis' yang berarti sebagai to stand by (previous) decisions (berpegang/berpatokan pada putusan-putusan sebelumnya). ${ }^{5}$

\section{Relevansi Civil Law dan Common Law dalam Perkembangan Hukum di Indonesia}

Dalam mengkaji dan menelusuri relevansi sistem Common Law dan Civil Law dalam perjanjian baku di Indonesia maka perlu dipahami lebih dahulu keberadaan hukum di Indonesia, khususnya hukum perjanjian masih dianggap dibawah pengaruh hukum Romano-Germanic (Civil Law) berdasarkan tradisi dan sejarah. Menurut Ifdhal Kasim, bahwa masuknya arus utama aliran pemikiran hukum ini ke bumi Indonesia, selain memang karena dampak dari kolonisasi pemerintah Hindia Belanda, juga tidak dapat dilepaskan dari peranan kaum academic jurist Belanda yang mengawali tonggak pengajaran dan kajian hukum di sini. Sebagai negara yang meneruskan tradisi Civil Law, perkembangan hukum sangat ditentukan oleh academic jurist karena ia memiliki kewenangan akademik dan profesional dalam menginterpretasi hukum. Hal ini membedakan dengan negara yang di bawah tradisi Common Law, dimana perkembangan hukumnya ditentukan oleh kaum profesional lawyers, seperti hakim dan pengacara sehingga memungkinkan lahirnya berbagai aliran pemikiran dalam memahami hukum di luar aliran pemikiran yang dominan. ${ }^{6}$

\footnotetext{
${ }^{5}$ Hardiyan Rusli, Hukum Perjanjian..., 16

${ }^{6}$ Ifdhal Kasim, Membebaskan Hukum dalam Wacana ( Yogyakarta: Insist Press, 2000)..., h 4
} 
Common Law yang lahir dan berkembang dalam keadaan khusus baik berdasarkan sejarah maupun kebudayaan Inggris dan negara-negara yang terkait dengannya, pada awalnya belum berpengaruh dan tidak sesuai terhadap keberadaan hukum di Indonesia. Di dalam perkembangannya pengaruh Common Law makin terasa di Indonesia karena semenjak komunitas hukum berinteraksi dengan kekuatan ekonomi internasional dan tidak dapat diingkari bahwa bahasa Inggris menjadi bahasa pergaulan dunia yang utama. Adapun pengaruh Common Law yang bersifat mendunia adalah penggunaan istilah-istilah Common Law dalam perjanjian bisnis internasional, seperti halnya mortgage, in consideration of, liquidated damages, dan lainlain. ${ }^{7}$

\section{Metode Penelitian}

Sudut pandang pengkajian permasalahan pengaturan hukum perjanjian baku adalah bertolak dari sudut normatif, yakni untuk mengetahui dan memaparkan perkembangan (dinamika) internal hukum. Istilah penelitian hukum normatif menurut Soerjono Soekanto dan Sri Mamudji adalah penelitian hukum kepustakaan, yang bisa disejajarkan dengan istilah legal research atau legal research instruction. ${ }^{8}$ Bertolak dari pemahaman penelitian hukum normatif di atas, maka pendekatan terhadap permasalahan tersebut dilakukan melalui conceptual approach, statute approach dan comparative approach. ${ }^{9}$

Dalam rangka pengumpulan bahan hukum untuk penelitian ini dilakukan dengan prosedur sebagai berikut: Penelusuran terhadap peraturan perundang-undangan yang berkaitan dengan pengaturan hukum perjanjian baku di Indonesia. Bahan-bahan hukum

\footnotetext{
${ }^{7}$ Djasadin Saragih, Sekilas Perbandingan Hukum Kontrak Civil Law dan Common Law dalam Hukum Kontrak di Indonesia (Jakarta: ELIPS, 1998)..., h 2.

${ }^{8}$ Soerjono Soekanto,\& Sri Mamudji, Penelitian Hukum Normatif: Suatu Tinjauan Singkat. (Jakarta: Rajawali Press)..., h 27.

${ }^{9}$ Philipus Mandiri Hadjon, Pengkajian Ilmu Hukum dalam Pelatihan Metode Penelitian Hukum Normatif, Pusat Penelitian dan Pengembangan Hukum Lembaga Penelitian Universitas Airlanggga Bekerjasama dengan Fakultas Hukum Universitas Airlangga, Surabaya, 1112 Juni 1997.
}

yang berasal dari peraturan perundang-undangan tersebut merupakan bahan hukum primer yang diharapkan dapat mencerminkan pengaturan hukum perjanjian baku yang berlaku bagi para pelaku bisnis. Berikutnya, penelusuran bahan hukum sekunder melalui bahan kepustakaan (buku-buku, karangan-karangan ilmiah, pendapat para ahli) yang membahas masalah pengaturan hukum perjanjian baku yang digunakan sebagai pelengkap untuk memberikan gambaran sebenarnya maupun penafsiran terhadap ketentuan hukum perjanjian baku.

Langkah penelitian ini dilakukan dengan menganalisis isi dan struktur hukum untuk menghasilkan pengaturan yang sebenarnya tentang perjanjian baku di Indonesia. Analisis hukum merupakan sistem terbuka, yang berarti bahwa aturan hukum harus dipikirkan dalam suatu hubungan dari norma hukum yang bertumpu atas asas dan konsep hukum. Dalam langkah kajian ini digunakan penafsiran hukum yang meliputi :

Penafsiran historis, yaitu penafsiran atas risalah proses pembuatan peraturan-perundangan;

Penafsiran teleologis, yaitu penafsiran tentang latar belakang tujuan diterbitkannya peraturan-perundangan tersebut apakah masih sesuai dengan keadaan yang dihadapi;

Penafsiran gramatikal, yaitu penafsiran sesuai makna kata yang digunakan dalam ketentuan hukum. ${ }^{10}$

\section{Hasil dan Pembahasan}

\section{Praktik Hukum di Indonesia: Perjanjian Baku di bawah Pengaruh Sistem Civil Law dan Common Law}

Sebelum mengkaji perkembangan perjanjian baku di Indonesia maka perlu dipahami lebih dulu bahwa secara tradisional suatu perjanjian terjadi berlandaskan asas kebebasan berkontrak diantara dua pihak yang mempunyai kedudukan yang seimbang dan ${ }^{10}$ P.M. Marzuki, Penelitian Hukum. Dalam Pelatihan Metode Penelitian Hukum Normatif, Pusat Penelitian dan Pengembangan Hukum Lembaga Penelitian Universitas Airlanggga Bekerjasama dengan Fakultas Hukum Universitas Airlangga, Surabaya, 11-12 Juni 1997. 
kedua belah pihak berusaha untuk mencapai kesepakatan yang diperlukan bagi terjadinya perjanjian itu melalui proses negosiasi di antara mereka. Namun pada perkembangannya ada kecenderungan makin memperlihatkan bahwa banyak perjanjian didalam transaksi bisnis yang terjadi bukan melalui proses negosiasi yang seimbang di antara para pihak, tetapi perjanjian itu terjadi dengan cara di pihak yang satu telah menyiapkan syarat-syarat baku pada suatu formulir perjanjian yang sudah dicetak dan kemudian disodorkan kepada pihak lainnya untuk disetujui dengan hampir tidak memberikan kebebasan sama sekali kepada pihak lainnya untuk melakukan negosiasi atau syaratsyarat yang disodorkan.

Mariam Darus Badrulzaman menyatakan bahwa pada asasnya bentuk perjanjian itu bebas. Perjanjian tidak terikat pada bentuk tertentu dapat lisan atau tertulis. Di dalam praktek perjanjian ini tumbuh sebagai perjanjian dalam bentuk tertulis. ${ }^{11}$ Perbuatan hukum sejenis yang selalu terjadi berulang-ulang dan teratur yang melibatkan banyak orang, menimbulkan kebutuhan untuk mempersiapkan isi perjanjian itu terlebih dahulu dan kemudian dibakukan dan seterusnya dicetak dalam jumlah yang banyak sehingga memudahkan penyediaan setiap saat jika masyarakat membutuhkannya. Perjanjian yang demikian ini menurut Sutan Remi Syahdeni dinamakan perjanjian standar, perjanjian baku atau perjanjian adhesi. ${ }^{12}$

Penggunaan perjanjian baku dalam kehidupan bermasyarakat dan khususnya di kalangan dunia bisnis sudah lazim. Namun penggunaan perjanjian baku ini bukan tanpa menghadapi masalah-masalah hukum yang mendapat sorotan para ahli hukum, yaitu seperti antara lain dikemukakan oleh P.S. Atiyah dalam Sutan Remy Syahdeni: 'By mid-century these standard-form contracts had become one of the mayor problems of the law of contract'. Beranjak dari pemahaman ini maka dapat dikemukakan masalah-masalah yang dihadapi dalam penggunaan perjanjian baku

\footnotetext{
${ }^{11}$ Mariam Darus Badrulzaman , Perjanjian Baku ..., h 51

${ }^{12}$ Sutan Remi Syahdeni, Kebebasan Berkontrak ...,h 66
}

adalah yang pertama berkenaan dengan keabsahan dari perjanjian baku itu dan yang kedua sehubungan dengan pemuatan klausulklausul atau ketentuan-ketentuan yang secara tidak wajar sangat memberatkan bagi pihak lainnya. ${ }^{13}$

\section{Perihal Persyaratan Tertulis (Statue of Frauds)}

Dalam praktek hukum di Indonesia sudah berlaku aturan-aturan tersendiri untuk perjanjian-perjanjian khusus yang dimuat di dalam BabV- Bab XVIII Buku III Kitab Undang-Undang Hukum Perdata (yang dianggap dibawah pengaruh Hukum Romawi) yang bersifat sebagai pelengkap, sehingga pada dasarnya dapat disimpangi oleh para pihak. Hal ini berarti terbukanya kesempatan yang begitu luas untuk membuat perjanjian berdasarkan asas kebebasan berkontrak yang tersurat dalam pasal 1338 (1) Kitab Undang-Undang Hukum Perdata. Hal ini sangat berbeda dengan pengaruh hukum Anglo Amerika (Common Law) yang selama periode tertentu tidak berdasarkan aturanaturan khusus sehingga besar kemungkinan perjanjian tersebut dirumuskan secara panjang lebar dan lebih rinci. Dengan demikian di dalam tradisi Common Law tidak begitu dibutuhkan aturan-aturan tersendiri untuk perjanjian-perjanjian khusus yang bersifat pelengkap. Perjanjian-perjanjian khusus baru dibuat ketika timbul kebutuhan akan aturan-aturan khusus yang bersifat memaksa (imperative).

Perjanjian-perjanjian baik yang dibawah pengaruh Common Law maupun Civil Law sistem keduanya tidak menentukan atau memaksakan adanya persyaratan tertulis (statue of frauds). Hal demikian berarti kebanyakan perjanjian yang dibuat adalah sah meskipun dilakukan dalam bentuk lisan atau tidak dalam bentuk tertulis. Statue of frauds ditetapkan di Inggris pada tahun 1667 karena bertujuan untuk menghindari atau menolak tuntutan yang bersifat penipuan (fraudulent claims) dengan menentukan syarat bagi yang mengajukan claim untuk mempelihatkan

\footnotetext{
${ }^{13}$ Sutan Remi Syahdeni, Kebebasan Berkontrak ..., h 66
} 
atau mengajukan sesuatu yang tertulis agar dapat membuktikan claim tersebut. Hal ini dapat dipahami bahwa banyak perjanjianperjanjian yang dilakukan secara lisan baik yang terjadi dalam sistem Civil Law, Common Law maupun sistem yang lain akan menghadapi persoalan pembuktian di pengadilan. ${ }^{14}$

\section{Perihal Keabsahan Perjanjian Baku}

Sehubungan dengan permasalahan keabsahan perjanjian baku maka dapat dipahami bahwa di Indonesia yang diyakini menganut tradisi Civil Law akan berpijak pada ketentuan pasal 1320 Kitab Undang-Undang Hukum Perdata yang menentukan empat syarat sahnya perjanjan yaitu kesepakatan, kecakapan, obyek tertentu, dan causa yang halal. Menurut Common Law, keabsahan perjanjian mensyaratkan kesepakatan, kecakapan, obyek tertentu dan ditambahkan unsur penting yaitu consideration. Makna consideration hampir sama dengan makna causa dalam Code Civil Perancis yaitu prestasi yang dilakukan atau disanggupkan oleh para pihak. Makna causa menurut Pitlo dalam Djasadin Saragih adalah apa yang diinginkan para pihak. Cau$s a$ tidak lain daripada isi perjanjian yang selanjutnya tidak boleh bertentangan dengan undang-undang, kesusilaan, dan ketertiban umum. ${ }^{15}$

Menurut Asser-Rutten dalam Mariam D.B, bahwa asas esensial dari hukum perjanjian adalah sepakat mereka yang mengikatkan dirinya. Asas ini dinamakan juga asas konsensualisme yang menentukan adanya (raison d'etre) perjanjian. ${ }^{16}$ Demikian pula dalam hukum Inggris, asas ini dikenal juga dalam Anson's Law of Contract. Asas konsensualisme ini bersifat universal karena ada baik di wilayah Common Law maupuan Civil Law in casu hukum perjanjian di Indonesia. ${ }^{17}$

Asas konsensualisme ini mempunyai hubungan yang erat dengan asas kebebasan berkontrak dan asas kekuatan mengikat

\footnotetext{
${ }^{14}$ Djasadin Saragih , Sekilas Perbandingan Hukum..., h 3-4

${ }^{15}$ Djasadin Saragih, Sekilas Perbandingan Hukum..., h 4

${ }^{16}$ Mariam Darus Badrulzaman, Perjanjian Baku..., h 81

${ }^{17}$ Djasadin Saragih, Sekilas Perbandingan Hukum..., h 4
}

yang terdapat di dalam pasal 1338 Kitab Undang-Undang Hukum Perdata. Asas kebebasan berkontrak berhubungan dengan isi perjanjian yaitu kebebasan menentukan apa dan dengan siapa perjanjian itu akan diadakannya.

Perjanjian yang dibuat sesuai dengan pasal 1320 Kitab Undang-Undang Hukum Perdata ini mempunyai kekuatan mengikat. Kalau dikaji masalah 'ada' dan 'kekuatan mengikat' perjanjian baku maka secara teoritis juridis, perjanjian ini tidak memenuhi elemen yang dikehendaki pasal 1320 jo 1338 Kitab Undang-Undang Hukum Perdata. Hal ini berdasarkan alasan bahwa perbedaan posisi para pihak ketika perjanjian baku diadakan adalah tidak memberikan kesempatan pada debitur untuk mengadakan 'real bargaining' dengan kreditur.

Menurut Hondius, didalam perjanjian baku terdapat pelanggaran terhadap asas kebebasan berkontrak. Hal tersebut merupakan pendirian umum Inggris. Dengan demikian secara teoritis juridis perjanjian baku ini tidak memenuhi ketentuan Undang-Undang dan beberapa ahli hukum menolaknya. Namun kenyataannya kebutuhan masyarakat berjalan dalam arah yang berlawanan dengan keinginan hukum. ${ }^{18}$

Di dalam perkembangannya perlu dikemukakan pendapat beberapa ahli hukum diantaranya Stein mengatakan bahwa perjanjian baku dapat diterima sebagai perjanjian berdasarkan fiksi adanya kemauan dan kepercayaan yang membangkitkan pemahaman bahwa para pihak mengikatkan diri pada perjanjian itu. Jika debitur menerima dokumen perjanjian itu berarti ia secara sukarela setuju pada isi perjanjian tersebut. Berikutnya Asser Rutten mengatakan pula bahwa setiap orang yang menandatangani perjanjian bertanggungjawab pada isi dan apa yang ditandatanganinya. Jika ada orang yang membubuhkan tanda tangan pada formulir perjanjian baku, tanda tangan itu membangkitkan kepercayaan bahwa yang bertanda tangan mengetahui dan menghendaki isi formulir yang ditanda tangani. Hondius di ${ }^{18}$ Sutan Remi Syahdeni, Kebebasan Berkontrak..., h 66 
dalam disertasinya menyatakan bahwa perjanjian baku mempunyai kekuatan mengikat berdasarkan kebiasaan yang berlaku di lingkungan masyarakat dan lalu lintas perdagangan. ${ }^{19}$ Dalam hukum Inggris juga terdapat pandangan dari tulisan J.R. Spencer sebagai berikut:' where there is a signed document, the court that some kind of magic operated to take contract out of the usual rules that govern the formation of contract and to bind the signature almost absolutely'. ${ }^{20}$

Sutan Remy Syahdeini berpendapat bahwa keabsahan berlakunya perjanjian baku tidak perlu dipersoalkan oleh karena perjanjian baku eksistensinya sudah merupakan kenyataan yaitu dengan telah dipakainya perjanjian baku secara meluas dalam dunia bisnis sejak lebih dari 80 tahun lamanya. Kenyataan itu terbentuk karena perjanjian baku memang lahir dari kebutuhan masyarakat sendiri. Dunia bisnis tidak dapat berlangsung tanpa perjanjian baku. Perjanjian baku dibutuhkan oleh dan karena itu diterima masyarakat. Namun perlu ditentukan aturan-aturan dasarnya sebagai pegangan agar klausul-klausul atau ketentuan-ketentuan dalam perjanjian baku itu, baik sebagian atau seluruhnya mengikat para pihak. ${ }^{21}$

\section{Perihal Ingkar Janji (Break of Contract)}

Di dalam tradisi Civil Law perihal ingkar janji diatur bahwa jika terjadi wanprestasi oleh debitur maka timbullah tuntutan kreditur untuk pemenuhan, pembatalan/pembubaran, pemenuhan atau pembatalan dengan pembayaran ganti rugi sebagaimana tersebut dalam pasal 1236-1250 Kitab Undang-Undang Hukum Perdata. Menurut Djasadin Saragih bahwa hal ini berbeda dengan Common Law, jika terjadi ingkar janji (break of contract) maka timbulah tuntutan kreditur kepada debitur yang hanya membayar ganti rugi (damages) dan bukan pemenuhan prestatie (performance). Kalaupun dalam perkembangannya yang diinginkan adalah pemenuhan prestatie maka sebenarnya ber-

\footnotetext{
${ }^{19}$ Sutan Remi Syahdeni, Kebebasan Berkontrak..., h 66 ${ }^{20}$ Mariam Darus Badrulzaman, Perjanjian Baku..., h 6364

${ }^{21}$ Sutan Remi Syahdeni, Kebebasan Berkontrak..., h 71
}

dasarkan equety, sehingga disamping legal remedy (ganti rugi) termasuk juga equitable remedy (pemenuhan prestasi). ${ }^{22} \mathrm{Hal}$ ini dapat diambil contoh ketentuan pasal 1266 Kitab Undang-Undang Hukum Perdata yang menyatakan akan membubarkan perjanjian. Namun ketentuan ini sering disimpangi oleh para pihak dan hakim di dalam praktek dan menganggap aturan tersebut bersifat pelengkap.

Sejalan dengan pemikiran ini, break of contract yang diatur dalam Common Law menyatakan tidak setiap break of contract menimbulkan hak untuk membubarkan perjanjian karena terbatas pada pelanggaran yang berat (substansial). Namun secara umun dapat dikatakan bahwa kemungkinan pembubaran perjanjian di Indonesia lebih luas dibandingkan dengan common law system. Gugatan ganti rugi yang normal akibat wanprestasi adalah real damages atau ordinary damages. ${ }^{23}$

Di dalam prakteknya para pihak sewaktu penutupan perjanjian sudah menentukan jumlah ganti rugi yang harus dibayar apabila terjadi wanspretasi yang dinamakan liquidated damages. Hal ini harus dibedakan dari janji denda (pelnaties) yang menurut hukum Anglo-Amerika tidak dapat dipaksakan lain dengan hukum Indonesia (bandingkan pasal 1304 Kitab Undang-Undang Hukum Perdata). Liquidated damages dapat bermakna positif bagi para pihak yaitu bagi kreditor akan bebas dari beban pembuktian yang berat tentang besarnya jumlah kerugian yang dideritanya dan bagi debitur juga diuntungkan karena ia tidak akan dihadapkan dengan kejutan besarnya gantirugi yang harus dipikulnya.

\section{Perihal Klausula Eksonerasi di dalam Perjanjian Baku}

Masalah hukum berikutnya yang terpenting berkenaan dengan banyaknya penggunaan perjanjian-perjanjian baku di dunia bisnis adalah masalah yang berkaitan dengan pencantuman klausul-klausul atau ketentuan yang secara tidak wajar sangat memberatkan bagi pihak lainnya. Di antara klausul-klausul

\footnotetext{
${ }^{22}$ Djasadin Saragih, Sekilas Perbandingan Hukum..., h 6 ${ }^{23}$ Ibid..., h 6
} 
yang dinilai sebagai klausul yang memberatkan dan yang banyak muncul dalam perjanjian - perjanjian baku menurut Sutan Remy Syahdeini, adalah yang disebut klausul eksemsi. ${ }^{24}$ Menurut Mariam Darus Badrulzaman, bahwa untuk penamaan klausul ini dapat menggunakan istilah klausula eksonerasi sebagai terjemahan exoneratie clausule yang dipakai dalam bahasa Belanda. ${ }^{25}$

Pengertian hukum dari klausul eksemsi menurut para ahli hukum diantaranya adalah Mariam Darus Badrulzaman yang menyatakan bahwa sebagai klausul yang berisi pembatasan pertanggungan jawab dari kreditor. ${ }^{26}$ Berikutnya menurut David Yates dalam Sutan Remy Syahdeini adalah: 'any term in a contract restricting, excluding or modifying a remedy or a liability arising out of a contractual obligation.' Dari pemahaman tersebut dapat diartikan bahwa klausul eksemsi adalah klausul yang bertujuan untuk membebaskan atau membatasi tanggung jawab salah satu pihak terhadap gugatan pihak lainnya dalam hal yang bersangkutan tidak atau tidak dengan semestinya melaksanakan kewajibannya yang ditentukan di dalam perjanjian tersebut. ${ }^{27}$

Klausul-klausul eksemsi dapat muncul dalam berbagai bentuk. Menurut Sutan Remy Syahdeini yang mengutip pendapat David Yates, bahwa klausul tersebut dapat berbentuk pembebasan sama sekali dari tanggung jawab yang harus dipikul oleh pihaknya apbila terjadi ingkar janji (wanprestasi). Selain itu dapat pula berbentuk pembatasan jumlah ganti rugi yang dapat dituntut atau berbentuk pembatasan waktu bagi orang yang dirugikan untuk dapat mengajukan gugatan atau ganti rugi. Dalam hal yang terakhir ini batas waktu tersebut lebih pendek dari yang ditentukan oleh undang-undang bagi seseorang untuk dapat mengajukan gugatan atau ganti rugi. ${ }^{28}$

Klausul eksemsi hanyalah salah satu per-

\footnotetext{
${ }^{24}$ Sutan Remy Syahdeini, Kebebasan Berkontrak..., h 72

${ }^{25}$ Mariam Darus Badrulzaman , Perjanjian Baku..., h 109

${ }^{26}$ Ibid , Perjanjian Baku..., h 109

${ }^{27}$ Sutan Remy Syahdeini, Kebebasan Berkontrak..., h 75

${ }^{28}$ Sutan Remy Syahdeini, Kebebasan Berkontrak..., h 76
}

wujudan dari klausul yang secara tidak wajar sangat memberatkan. Suatu klausul yang tidak membebaskan atau membatasi tanggung jawab salah satu pihak terhadap gugatan pihak lainnya dapat saja diperkirakan sebagai memberatkan pihak lainnya. Misalkan apabila di dalam praktek perjanjian kredit bank di Indonesia ada ketentuan yang memberikan hak kepada bank untuk tanpa ada alasan apapun juga menghentikan, baik untuk sementara maupun untuk selanjutnya izin tarik kredit oleh nasabah debitur.

Penggunaan perjanjian baku dalam transaksi bisnis di Indonesia semakin banyak sehingga sejogyanya memerlukan perhatian yang besar kepada aturan dasar yang harus dipatuhi oleh semua pihak dalam mempergunakan perjanjian baku, seperti halnya di negara-negara yang menganut sistem Common Law yaitu berpijak pada aturan-aturan dasar yang dikembangkan oleh berbagai yurisprudensi sehubungan dengan penerapan asas public policy dan unconscionability.

Menurut Sutan Remy Syahdeini, bahwa aturan dasar yang berupa moral, ketertiban umum, dalam pasal 1337, kepatutan dan atau keadilan dalam pasal 1339 serta itikad baik yang didalamnya terkandung keadilan dalam pasal 1338 ayat 1 Kitab Undang-Undang Hukum Perdata adalah sejalan dengan Public Policy dan Unconscionability dalam sistem Common Law. ${ }^{29}$

Di dalam perkembangannya hal ini terlihat dalam salah satu putusan Mahkamah Agung tanggal 14 Maret 1987 No 3431 K/ Pdt/1985 berkenaan dengan tolok ukur 'penyalahgunaan keadaan'. Konsep baru ini menurut Z. Asikin Kusumah Atmadja adalah untuk mencakup keadaan yang tidak dapat dimaksudkan dalam itikad baik, patut, dan adil atau bertentangan dengan ketertiban umum sebagai pengertian klasik karena akan memperkaya tolok ukur bagi hukum Indonesia dalam menentukan ada atau tidak adanya bargaining power yang seimbang dalam suatu perjanjian. ${ }^{30}$

\footnotetext{
${ }^{29}$ Sutan Remy Syahdeini, Kebebasan Berkontrak..., h 122123

${ }^{30}$ Ibid..., h 123-124
} 


\section{Kesimpulan dan Saran}

Di dalam era globalisasi yang telah melanda dunia, telah mengkondisikan berbagai warga negara untuk saling berhubungan dalam rangka memenuhi kebutuhan hidupnya. Hal demikian ini mengakibatkan terjadinya pertemuan antara berbagai sistem hukum yang ada dan bisa memenuhi kebutuhan hukum para pihak yang menjalankan kepentingannya. Pemenuhan kebutuhan hukum para pihak banyak dilakukan melalui perjanjian baku yang berlaku umum di masyarakat, baik yang menganut sistem Com-

\section{DAFTAR PUSTAKA}

Djasadin Saragih. 1998. Sekilas Perbandingan Hukum Kontrak Civil Law dan Common Law dalam Hukum Kontrak di Indonesia, Jakarta: ELIPS.

Hardijan Rusli, 1996. Hukum Perjanjian Indonesia dan Common Law, Cet. II, Jakarta: Pustaka Sinar Harapan.

Ifdhal Kasim, 2000: Membebaskan Hukum dalam Wacana, Edisi ke VI, Yogyakarta: Insist Press.

Mariam Darus Badrulzaman, 1981. Perjanjian Baku (Standard), Perkembangannya Di Indonesia dalam Kumpulan Pidato-Pidato Pengukuhan, Bandung: Alumni. mon Law maupun Civil Law in casu di Indonesia. Kedua sistem hukum ini mempunyai relevansi dalam pengembangan hukum perjanjian baku, diantaranya, perihal persyaratan tertulis (statue of frauds), perihal keabsahan perjanjian baku, perihal ingkar janji (break of contract) dan perihal klausula eksonerasi yang tercantum dalam perjanjian baku. Pengaturan tersebut sejogyanya perlu dibakukan demi kepastian hukum dan memenuhi keadilan bagi para pihak sekaligus memberikan kemanfaatan bagi pemenuhan kebutuhan hukum masyarakat Indonesia.

$-1981$

Perlindungan Terhadap Konsumen Dilihat Dari Sudut Perjanjian Baku (Standard) dalam Pembentukan Hukum Nasional Dan Permasalahannya, Bandung: Alumni.

Soetandyo Wignyosoebroto, 1994. Dari Hukum Kolonial Ke Hukum Nasional: Suatu Kajian Dinamika Sosial Politik Dalam Perkembangan Hukum Di Indonesia, Jakarta: Raja Grafindo Persada.

Sutan Remy Syahdeini, 1997. Kebebasan Berkontrak dan Perlindungan yang Seimbang Bagi Para Pihak Dalam Perjanjian Kredit Bank Di Indonesia, Jakarta: Institut Bankir Indonesia. 